\title{
Estimation of Aerodynamic and Canopy Resistances in a Mediterranean Greenhouse Based on Instantaneous Leaf Temperature Measurements
}

\author{
Georgios Nikolaou ${ }^{1, * \mathbb{C}}$, Damianos Neocleous ${ }^{2}{ }^{\mathbb{D}}$, Evangelini Kitta ${ }^{1}$ and Nikolaos Katsoulas ${ }^{1}[$ \\ 1 Department of Agriculture Crop Production and Rural Environment, School of Agricultural Sciences, \\ University of Thessaly, Fytokou Str., 38446 Volos, Greece; evkitta@uth.gr (E.K.); nkatsoul@uth.gr (N.K.) \\ 2 Department of Natural Resources and Environment, Agricultural Research Institute, Ministry of Agriculture, \\ 1516 Nicosia, Cyprus; d.neocleous@ari.gov.cy \\ * Correspondence: gnicolaounic@gmail.com; Tel.: +30-24-2109-3249
}

Received: 10 November 2020; Accepted: 15 December 2020; Published: 17 December 2020

\begin{abstract}
Aerodynamic and canopy resistances have long been considered to be of key interest in model equation parameterization, particularly for the accurate estimation of crop evapotranspiration. However, model parameters applied in greenhouses showed variation affected by the micrometeorological environment. Three experiments were carried out in a plastic greenhouse to evaluate microclimate effects on resistances of a soilless cucumber crop. The regression analysis of canopy-to-air temperature $\left(T_{c}-T_{a}\right)$ difference on air vapor pressure deficit (VPD) was substituted into the energy balance equation for the estimation of aerodynamic and canopy resistance values. As expected, a fan and pad evaporative cooling system proved to be the more efficient method of decreasing crop temperature $\left(T_{\mathcal{c}}\right)$ compared to the forced air ventilation system. The estimated transpiration by the Penman-Monteith model based on calculated aerodynamic and canopy resistance values successfully validated values measured with lysimeters in different growing periods. In this article, we report for the first time the calculation of aerodynamic and canopy resistance values inside a greenhouse based on equations for an open field that were found in the literature. Results may be helpful in Mediterranean greenhouses for direct determinations of plant water evaporative demand and smart climate control systems.
\end{abstract}

Keywords: canopy-to-air temperature; energy balance equation; transpiration; fan and pad evaporative cooling system; forced ventilation; soilless culture

\section{Introduction}

Transpiration is an important component of canopy energy and water balance that should be considered, especially for plastic greenhouses in semi-arid regions. Under these conditions, transpiration depends mainly on convection rather than decoupling from the outside atmosphere by the presence of the glass [1]. Therefore, understanding the transpiration process with a focus on the coupling between the greenhouse microclimate and crop is helpful for adopting proper irrigation and climate control management [2,3]. Kimura et al. [4] have demonstrated that the spatiotemporal distribution of leaf boundary layer conductance within a tomato crop canopy may be a useful tool for appropriate microclimate assessment in the greenhouse.

Maintaining high transpiration rates during the day could be a method of cooling a greenhouse and less outflow of drainage emissions into the environment $[5,6]$. The Penman-Monteith (P-M) equation was the first mathematical model used for open-field estimation of transpiration, (usually) on a daily basis based on the energy balance of the "big-leaf" approach [7]. The model treated the crop canopy as a 
single leaf, instead of a three-dimensional crop, where all the net radiation was absorbed and from where water vapor and heat escaped [8]. However, problems still exist in the practical application of the P-M equation, namely, in the calculation of the aerodynamic resistance (i.e., resistance from the vegetation upward which involves friction from air flowing over vegetative surfaces; $r_{a}$ ) and surface resistance (i.e., resistance of vapor flow through stomata openings, the total leaf area and the soil surface; $r_{s}$ ) $[9,10]$. Crop resistance increases when there is a shortage of water, which limits transpiration. In addition, it is affected to some extent by radiation intensity, vapor pressure deficit and air temperature [8]. Therefore, the P-M formula has been mainly applied as a diagnostic tool for estimating $r_{s}$ for a known transpiration rather than as a prognostic tool for estimating transpiration when the $r_{s}$ is assumed; mainly because $r_{s}$ is affected by prevailing climatic conditions [11]. Allen et al. [12] recommended mean daytime $r_{s}$ values between 50 to $70 \mathrm{~s} \mathrm{~m}^{-1}$ and $200 \mathrm{~s} \mathrm{~m}^{-1}$ at night for a standardized height of $0.12 \mathrm{~m}$ for clipped grass. Models and logarithmic functions, which describe the turbulent transfer of water vapor between a leaf and the atmosphere related to crops' geometry characteristics and the speed of air, mainly apply to open field $r_{a}$ calculations. However, within greenhouses under low wind speed conditions, $r_{a}$ tends towards infinity, so these methods may not be recommended [13]. In any case, the analog of Ohm's law, which describes the water flux resistances through the soil-root-stem-leaf-atmosphere system, indicates that the transpiration rate is inversely proportional to the total resistance $\mathrm{R}$ (seconds) and proportional to the total head difference, $\Delta \mathrm{h}_{\text {total }}(\mathrm{cm})[14]$.

In a greenhouse, several transpiration models have been used with their accuracy pertain to the estimation of crop resistance values and the radiation absorption coefficient [7]. The most commonly used transpiration model in greenhouses is the P-M equation-used many times before and applied in a time scale of minutes. It uses canopy resistance $\left(r_{c}\right)$ instead of surface resistance, as greenhouse crops are frequently mulched [15]. However, differences in greenhouse types and equipment, the slow air movement (in greenhouse conditions, the logarithmic law of the wind is not applied), rapid changes in microclimatic conditions and frequent irrigation present additional challenges to calculating crop and aerodynamic resistance within greenhouses [16]. Calculation variations of aerodynamic and canopy resistance values between studies, and differences, which often occur in the transpiration estimation during and after an irrigation event, suggest that these parameters may not only be crop specific but site specific too [17].

The effect of greenhouse microclimate on crop transpiration has been a topic of several investigations in the past; however, research on diurnal changes of crop resistances is scarce $[18,19]$. Indeed, $r_{c}$ can be estimated indirectly by measuring stomatal conductance $\left(r_{c}\right.$ is the inverse of stomatal conductance) with porometers or directly with leaf gas exchange systems [20-22]. Nevertheless, parameterizing the $r_{c}$ in distributed climate models over short time intervals with the addition of transfers through the substrate-plant-atmosphere continuum calculation can aid in developing efficient water and climate control [3,23].

Kittas et al. [24] stated that in Mediterranean greenhouses a constant $r_{c}$ value could be used for estimating evapotranspiration as it did not significantly influence the rate of transpiration. In contrast, Zolnier et al. [25], working with a hydroponic lettuce crop indicated, that when a constant $r_{c}$ value was used, the rate of transpiration was overestimated with the P-M equation in the early morning and afternoon hours. Yan et al. [26] suggested that days after transplanting and the height of cucumber were the primary influencers of $r_{c}$ values rather than the radiation value.

Some authors suggested that a constant $r_{a}$ value should be only applied in time periods when the greenhouse is kept closed or under very low wind in natural ventilated greenhouse conditions [27]. Baille et al. [28] reported that mean $r_{a}$ constant values ranged between 75 and $495 \mathrm{~s} \mathrm{~m}^{-1}$ for nine ornamental species, whereas Fernández et al. [29] accurately estimated the daily transpiration rate of a perennial grass crop in a plastic greenhouse with a fixed $r_{a}$ value of $150 \mathrm{~s} \mathrm{~m}^{-1}$.

In view of the above, the main objectives of this work were (1) to parameterize the aerodynamic $\left(r_{a}\right)$ and canopy resistances $\left(r_{c}\right)$ of a soilless cucumber crop based on instantaneous leaf temperature measurements, (2) to provide insight into the interdependency of various climatic variables on 
resistances, and (3) to recommended mean resistance values to be used for proper transpiration estimation and climate control in Mediterranean greenhouses.

\section{Materials and Methods}

\subsection{Site and Experiments}

Three experiments were conducted in a plastic gutter-connected greenhouse at the Agricultural Research Institute, Cyprus, in the coastal area of southern Cyprus (lat. $33^{\circ} 44^{\prime} \mathrm{N}$, long. $33^{\circ} 19^{\prime} \mathrm{E}$, altitude $5 \mathrm{~m}$ ). The greenhouse had three single greenhouse rooms (see Figure 1) with a total covered area of $504 \mathrm{~m}^{2}$ (24 m in length and $21 \mathrm{~m}$ in width) and was oriented in a north-south direction. The height of the gutters was $3.50 \mathrm{~m}$, and the ridge height was $5.0 \mathrm{~m}$. The greenhouse cover was an anti-drip low-density clear polyethylene (200 microns thick) film with $55 \%$ diffused light transmission, $88 \%$ thermal efficiency and $88 \%$ global light transmission. The greenhouse floor was completely covered by white plastic film. Natural ventilation was provided by a single continuous roof vent in the middle span with a maximum opening area of $24 \mathrm{~m}^{2}(24 \mathrm{~m}$ in length and $1 \mathrm{~m}$ in width) and a side vent at one wall with a maximum opening area equal to $52.8 \mathrm{~m}^{2}$ (18 $\mathrm{m}$ in length and $2.20 \mathrm{~m}$ in width). The sidewall and the roof inlet openings were covered of an insect-proof screen. The greenhouse was divided into two independent compartments by a plastic film, with one compartment composed by one span and the other of two spans (Figure 1). Each compartment had a different control system for controlling the greenhouse microclimate. In the first and second experimental periods (March to June, Exp.1; October to December, Exp.2), the climatic treatments were:

- $\quad$ Fan and pad evaporative cooling $\left(\mathrm{F}-\mathrm{P}_{\mathrm{E}}\right)$ combined with natural and a forced air ventilation system in the two-spans greenhouse;

- A forced air ventilation $\left(\mathrm{F}_{\mathrm{V}}\right)$ system in one-span greenhouse compartment.
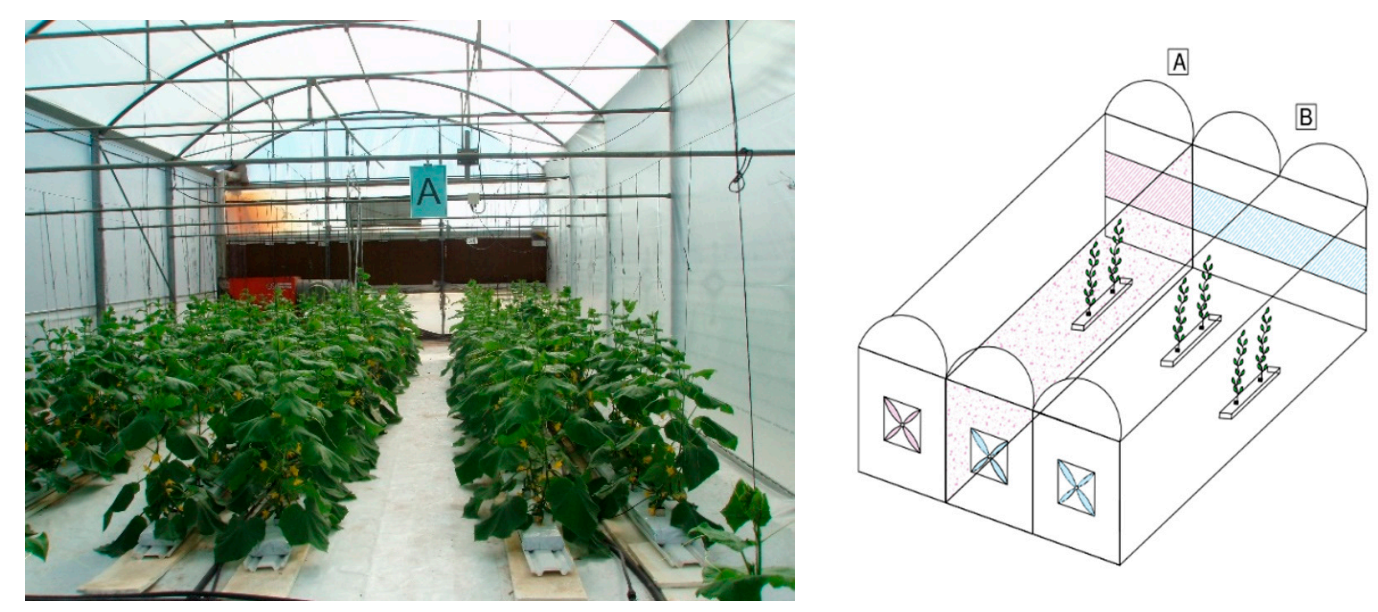

Figure 1. A photo of cucumber grown in the one greenhouse span (left); a greenhouse span (right) with a forced air ventilation $\left(\mathrm{F}_{\mathrm{V}}\right)$ system $(\mathrm{A})$ and a fan and pad evaporative cooling $\left(\mathrm{F}-\mathrm{P}_{\mathrm{E}}\right)$ combined with natural and forced air ventilation system (B).

In the third experimental period, the following year (March to June, Exp.3), whitewash was applied (suspension of calcium carbonate) to the roof and side walls of one of the spans of the greenhouse (i.e., to the climatic treatment with the forced air ventilation; $\mathrm{W}-\mathrm{F}_{\mathrm{V}}$ ).

The ventilation system started operating independently in each compartment when the greenhouse air temperature exceeded $25^{\circ} \mathrm{C}$ and $26^{\circ} \mathrm{C}$ in the first and second spans of the greenhouse, respectively. The air flow rate of each fan was $31,500 \mathrm{~m}^{3} \mathrm{~h}^{-1}$. The fan and pad evaporative cooling system consisted of a $0.15 \mathrm{~m}$ thick cellulose pad located on the south gable end wall that was $14 \mathrm{~m}$ in width and $1.2 \mathrm{~m}$ 
in height, with the bottom edge $1.3 \mathrm{~m}$ above ground level. It started operating when the greenhouse air temperature exceeded $27^{\circ} \mathrm{C}$. During winter, an air heater was used to maintain the minimum air temperature above $12{ }^{\circ} \mathrm{C}$ in both climatic treatments.

This work was conducted with the same trials reported by Nikolaou et al. [6,30], evaluating the effects of cooling systems and whitewash on greenhouse microclimate and cucumber growth. The current research reports data of aerodynamic and canopy resistances in a plastic greenhouse based on instantaneous leaf temperature measurements.

\subsection{Crop Details}

Seeds of the cucumber (Cucumis sativus L. cv. Phenomenon) were sown on rockwool starter blocks $(10 \times 10 \times 6.5 \mathrm{~cm})$ and seedlings $(\mathrm{n}=360)$ were transplanted into rockwool slabs $(100 \mathrm{~cm} \times 20 \mathrm{~cm} \times 7.5 \mathrm{~cm})$ (Grodan Company, Denmark) at the stage of two-three true leaves, resulting in a plant density of $1.6 \mathrm{pl} . \mathrm{m}^{-2}$. The number of plants was 120 in each greenhouse span. Polyethylene twine was attached $2.2 \mathrm{~m}$ above the plant row on a horizontal wire for supporting the plants. The plants were pruned to conform to the umbrella system, by removing all lateral branches until the plants reached the overhead support wire. Twelve days after transplanting, plants were irrigated at a rate of $0.24 \mathrm{~L} \mathrm{~m}^{-2}$ at fixed time intervals using standard grower practices. Then, the irrigation amount was increased to $0.32 \mathrm{~L} \mathrm{~m}^{-2}$ to maintain the drainage fraction close to $35-40 \%$ in each climatic treatment. A pyranometer located outside the greenhouse was used for calculating the frequency of irrigation based on solar radiation values following Katsoulas et al. [31]. An irrigation event was triggered by the integral of solar radiation intensity and regularly adjusted as plants grew. Plants were also irrigated at night-time to account for evaporation from the substrate during the dark hours, thus preventing the substrate from drying out [32]. Nutrient solution was applied in all irrigation events with composition based on recommendations of Savvas et al. [33].

\subsection{Measurements}

An automatic weather station was set up outside the greenhouse. Weather parameters recorded were the net solar radiation ( $\mathrm{RGo}, \mathrm{W} \mathrm{m}^{-2}$; sensor pyranometer type TIR-4P; Bio Instruments Company, Chisinau, Moldova), air temperature $\left(\mathrm{Ti},{ }^{\circ} \mathrm{C}\right)$ and relative humidity $(\mathrm{RH}, \%$; sensor type PT 100 ; Galcon, Kfar Blum, Israel). In each greenhouse compartment, sensors of the same type were used for monitoring climatic variables. Air temperature and relative humidity were both measured at $1.20 \mathrm{~m}$ above the ground and the net solar radiation at $2.2 \mathrm{~m}$ above the ground. All measurements were recorded with a data logger (Galileo controller; Galcon, Kfar Blum, Israel). Measurements were taken every $30 \mathrm{~s}$ and averaged every $10 \mathrm{~min}$.

Leaf temperature was monitored with a Phyto Sensor system (Bio Instruments Company, Chisinau, Moldova). The plant sensor network in each climatic treatment consisted of a leaf temperature sensor (Model LT-1z) that was regularly adjusted to crop growth and positioning according to the manufacturer's protocol. The probe consisted of high precision glass, about a millimeter in diameter, and an encapsulated thermistor with less than $0.15^{\circ} \mathrm{C}$ accuracy and a tolerance range of $\pm 0.08^{\circ} \mathrm{C}$. Data were transmitted every $10 \mathrm{~min}$ to the main system unit phyto-Logger with micro SD card and received by a PC.

A lysimeter, consisting of a plant supporting system with a rockwool slab of two plants in each treatment, was mounted on the greenhouse ceiling from a suspension load cell (Model 9363; Vishay Precision Group, Malvern, PA, USA; capacity of $50 \mathrm{Kg} ; \pm 0.02 \mathrm{~g}$ accuracy) for calculating the transpiration rate. The weight loss measured by the electronic balance was assumed to be equal to crop transpiration. 


\subsection{Theoretical Approach}

The energy fluxes between a leaf and its microclimate can be described by the energy balance equation $[12,34,35]$ :

$$
R_{n}=G+H+\lambda E
$$

where $R_{n}$ is the energy flux density of net incoming radiation $\left(\mathrm{W} \mathrm{m}^{-2}\right), G$ the soil heat flux density which could be neglected for greenhouse crops [8,36,37], $\lambda E$ is the latent heat flux density due to transpiration $\left(\mathrm{W} \mathrm{m}^{-2}\right), H$ is the sensible heat flux density from the leaf to the air $\left(\mathrm{W} \mathrm{m}^{-2}\right)$.

In their simplest forms, $H$ and $\lambda E$ can be determined as $[37,38]$ :

$$
\begin{gathered}
H=\frac{\rho C_{p}\left(T_{c}-T_{a}\right)}{r_{a}} \\
\lambda E=\frac{\rho C_{p}\left(e_{s}-e_{a}\right)}{\left[\gamma\left(r_{a}+r_{c}\right)\right]}
\end{gathered}
$$

where $\rho$ is the air density $\left(1.078 \mathrm{~kg} \mathrm{~m}^{-3}\right), C_{p}$ is the specific heat at constant pressure $\left(1013 \mathrm{~J} \mathrm{~kg}^{-1}{ }^{\circ} \mathrm{C}^{-1}\right)$, $T_{c}$ is the crop temperature $\left({ }^{\circ} \mathrm{C}\right), T_{a}$ the air temperature $\left({ }^{\circ} \mathrm{C}\right), e_{s}$ is the saturation vapor pressure at $T_{c}(\mathrm{kPa}), e_{a}$ is the actual vapor pressure $(\mathrm{kPa}),\left(e_{\mathrm{s}}-e_{a}\right)$ is saturation vapor pressure deficit $(\mathrm{kPa})$, $r_{a}$, is the aerodynamic resistance $\left(\mathrm{s} \mathrm{m}^{-1}\right), r_{c}$ is the canopy resistance $\left(\mathrm{s} \mathrm{m}^{-1}\right)$ and $\gamma$ is the psychrometric constant $\left(\mathrm{kPa} \mathrm{C}^{-1}\right)$.

However, $r_{c}$ values of a non-stressed crop could not be equal to zero; therefore, we could replace the psychrometric constant $\gamma$ with a modified psychrometric constant $\gamma^{*}$ [39]:

$$
\gamma^{*}=\gamma\left(1+\frac{r_{c p}}{r_{a p}}\right)
$$

where $r_{c p}$ is the canopy resistance $\left(\mathrm{s} \mathrm{m}^{-1}\right)$ and $r_{a p}$ is the aerodynamic resistance of a non-stressed $\operatorname{crop}\left(\mathrm{s} \mathrm{m}^{-1}\right)$.

Considering Equations (2)-(4), Equation (5) may be rewritten as [34]:

$$
T_{c}-T_{a}=\frac{r_{a p} R_{n}}{p C_{p}} * \frac{\gamma\left(1+\frac{r_{c p}}{r_{a p}}\right)}{\Delta+\gamma\left(1+\frac{r_{c p}}{r_{a p}}\right)}-\frac{V P D}{\Delta+\gamma\left(1+\frac{r_{c p}}{r_{a p}}\right)}
$$

where $\Delta$ is the slope of the saturation vapor pressure curve at temperature $\left(\mathrm{kPa}^{\circ} \mathrm{C}^{-1}\right)$.

In any case, the canopy-to-air temperature $\left(T_{c}-T_{a}\right)$ difference relationship and vapor pressure deficit (VPD) under clear sky conditions for a well-watered crop are linear [40]. Therefore, we can compute the intercept (a) and the slope (b) of the linear regression model of $T_{c}-T_{a}$ on VPD, where $a$ and $b$ are defined as below [41]:

$$
\begin{gathered}
a=\frac{r_{a p} R_{n}}{\rho C_{p}} * \frac{\gamma\left(1+\frac{r_{c p}}{r_{a p}}\right)}{\Delta+\gamma\left(1+\frac{r_{c p}}{r_{a p}}\right)} \\
b=-\frac{1}{\Delta+\gamma\left(1+\frac{r_{c p}}{r_{a p}}\right)}
\end{gathered}
$$

According to the same author, the mean aerodynamic and canopy resistance values over a period can be calculated using mean $R_{n}$ and $\Delta$ values as below:

$$
\bar{r}_{a p}=\frac{\rho C_{p} a}{\bar{R}_{n} b\left(\bar{\Delta}+\frac{1}{b}\right)}
$$




$$
\bar{r}_{c p}=-r_{a p}\left(\frac{\bar{\Delta}+\frac{1}{b}+1}{\gamma}\right)
$$

In our case, aerodynamic and canopy resistances were parameterized based on ten-minutes interval of leaf temperature and climatic variable measurements and averaged over the growing period.

\subsection{Penman-Monteith (P-M) Model Validation}

To validate the $\mathrm{P}-\mathrm{M}$ model, linear regression analysis was used to predict transpiration (based on estimated $\bar{r}_{a p}$ and $\bar{r}_{c p}$ values) in the same and different growing period (Equation (10)) [8].

$$
L E T=\frac{\Delta\left(R_{n}-G\right)+\frac{p C_{p}\left(e_{s}-e_{a}\right)}{\bar{r}_{a p}}}{\Delta+\gamma\left(1+\frac{\bar{r}_{c p}}{\bar{r}_{a p}}\right)}
$$

where $L$ is the latent heat of vaporization $\left(\mathrm{J} \mathrm{kg}^{-1}\right), E T$ is the evapotranspiration rate $\left(\mathrm{kg} \mathrm{m}^{-2} \mathrm{~s}^{-1}\right)$ and LET is the latent heat flux $\left(\mathrm{W} \mathrm{m}^{-2}\right)$.

\subsection{Statistical Analysis}

Data were analyzed and comparisons of means were tested with ANOVA using a Statistical Package for the Social Sciences (IBM Corp. Release 2011. IBM SPSS Statistics for Windows, Version 20.0. Armonk, NY, USA: IBM Corp).

\section{Results}

\subsection{Greenhouse Microclimate and Leaf Temperature}

The monthly mean external and internal greenhouse climatic parameters during daylight hours are presented in Table 1. Greenhouse air temperature and vapor pressure deficit values were significantly higher in the forced air ventilation climatic treatment $\left(\mathrm{F}_{\mathrm{V}}\right.$ and $\left.\mathrm{W}-\mathrm{F}_{\mathrm{V}}\right)$ as opposed to the fan and pad evaporative system $\left(\mathrm{F}-\mathrm{P}_{\mathrm{E}}\right)$. Maximum mean difference values of greenhouse air temperature between climatic treatments were $6.4^{\circ} \mathrm{C}$ (Exp.1) in May, $4.4^{\circ} \mathrm{C}$ (Exp.2) in November and $1.9^{\circ} \mathrm{C}$ (Exp.3) in March. In all climatic treatments, differences between external-internal greenhouse air temperatures became smaller as the plants grew. The mean average VPD differences between climatic treatments over the cropping seasons were $0.8 \mathrm{kPa}$ (Exp.1), $0.23 \mathrm{kPa}$ (Exp.2) and $0.19 \mathrm{kPa}$ (Exp.3). The maximum outside mean monthly solar radiation was $768 \mathrm{~W} \mathrm{~m}^{-2}$ observed in May (Exp.1) and the minimum $341 \mathrm{~W} \mathrm{~m}^{-2}$ observed in December (Exp.2). During Exp.1 and Exp.2, the crop inside greenhouse received 30-37\% less energy from global solar radiation than the outside. In Exp.3, whitewash application reduced global radiation transmittance through the greenhouse from $31 \%$ to $45 \%$ resulting in an average solar radiation difference between climatic treatments of $100 \mathrm{~W} \mathrm{~m}^{-2}$. In Exp.1 and Exp.3, relative humidity inside the greenhouse was close to that of the ambient air and in Exp.2 (November and December) higher than the ambient values (Table 1). Between climatic treatments, differences in relative humidity values were not as high as expected, even though water evaporated directly from the wetted evaporative-pad system within the one greenhouse span.

Higher negative values of canopy-to-air temperature differences $\left(T_{c}-T_{a}\right)$ were recorded in the forced air ventilation climatic treatment, despite seasonality (Table 1). The mean estimated $T_{c}-T_{a}$ differences over the cropping season in Exp. 1 were $-2.72{ }^{\circ} \mathrm{C} \mathrm{F}$ and $-1.49{ }^{\circ} \mathrm{C} \mathrm{F}-\mathrm{P}_{\mathrm{E}}$; in Exp.2 were $-3.78{ }^{\circ} \mathrm{C} \mathrm{F}$ and $1.84{ }^{\circ} \mathrm{C}$ F- $P_{\mathrm{E}}$; in Exp.3 were $-2.67{ }^{\circ} \mathrm{C} \mathrm{W}-\mathrm{F}_{\mathrm{V}}$ and $-2.17^{\circ} \mathrm{C}$ F- $\mathrm{P}_{\mathrm{E}}$. Considering different cropping periods, higher $T_{c}-T_{a}$ differences were observed in Exp. 2 compared with Exp.1 and Exp.3. 
Table 1. Mean values ( \pm standard error) of outside climatic data, leaf to air temperature differences and internal greenhouse microclimates for daylight hours.

\begin{tabular}{|c|c|c|c|c|c|c|}
\hline & March & \multicolumn{4}{|c|}{ Exp.1 } & May \\
\hline $\mathrm{T}_{\mathrm{o}}$ & \multicolumn{2}{|c|}{$20.9(0.10)$} & \multicolumn{2}{|c|}{$22.8(0.09)$} & \multicolumn{2}{|c|}{$28.0(0.08)$} \\
\hline $\mathrm{RH}_{\mathrm{O}}$ & \multicolumn{2}{|c|}{$57.4(0.04)$} & \multicolumn{2}{|c|}{$53.7(0.02)$} & \multicolumn{2}{|c|}{$55.8(0.03)$} \\
\hline $\mathrm{RG}_{\mathrm{o}}$ & \multicolumn{2}{|c|}{$585(9.81)$} & \multicolumn{2}{|c|}{$698(7.21)$} & \multicolumn{2}{|c|}{$768(7.05)$} \\
\hline & $\mathrm{F}_{\mathrm{V}}$ & $\mathrm{F}-\mathrm{P}_{\mathrm{E}}$ & $\mathrm{F}_{\mathrm{V}}$ & $\mathrm{F}-\mathrm{P}_{\mathrm{E}}$ & $\mathrm{F}_{\mathrm{V}}$ & $\mathrm{F}-\mathrm{P}_{\mathrm{E}}$ \\
\hline$T_{a}$ & $27.3(0.19)$ & $21.5(0.12)$ & $29.2(0.13)$ & $22.1(0.09)$ & $31.9(0.09)$ & $25.5(0.07)$ \\
\hline $\mathrm{RH}_{\mathrm{i}}$ & $57.6(0.49)$ & $58.2(0.42)$ & $56.2(0.34)$ & $58.5(0.32)$ & $57.3(0.31)$ & $59.1(0.27)$ \\
\hline $\operatorname{VPD}_{\mathrm{i}}$ & $2.1(0.03)$ & $1.3(0.01)$ & $2.0(0.02)$ & $1.3(0.01)$ & $2.3(0.02)$ & $1.4(0.01)$ \\
\hline$T_{c}-T_{a}$ & $-2.99(0.04)$ & $-1.27(0.03)$ & $-2.88(0.05)$ & $-1.81(0.03)$ & $-1.78(0.06)$ & $-1.30(0.07)$ \\
\hline \multirow[t]{2}{*}{$\mathrm{RG}_{\mathrm{i}}$} & \multicolumn{2}{|c|}{$407(6.83)$} & \multicolumn{2}{|c|}{$486(5.02)$} & \multicolumn{2}{|c|}{$534(5.22)$} \\
\hline & \multicolumn{2}{|c|}{ October } & \multicolumn{2}{|c|}{$\begin{array}{c}\text { Exp.2 } \\
\text { November }\end{array}$} & \multicolumn{2}{|c|}{ December } \\
\hline $\mathrm{T}_{\mathrm{o}}$ & \multicolumn{2}{|c|}{$27.7(0.11)$} & \multicolumn{2}{|c|}{$21.6(0.16)$} & \multicolumn{2}{|c|}{$21.3(0.20)$} \\
\hline $\mathrm{RH}_{\mathrm{o}}$ & \multicolumn{2}{|c|}{$56.3(0.28)$} & \multicolumn{2}{|c|}{$61.6(0.61)$} & \multicolumn{2}{|c|}{$71.3(0.68)$} \\
\hline $\mathrm{RG}_{\mathrm{o}}$ & \multicolumn{2}{|c|}{$531(5.90)$} & \multicolumn{2}{|c|}{$403(5.50)$} & \multicolumn{2}{|c|}{$341(6.71)$} \\
\hline & $\mathrm{F}_{\mathrm{V}}$ & $\mathrm{F}-\mathrm{P}_{\mathrm{E}}$ & $\mathrm{F}_{\mathrm{V}}$ & $\mathrm{F}-\mathrm{P}_{\mathrm{E}}$ & $\mathrm{F}_{\mathrm{V}}$ & F-P $P_{E}$ \\
\hline$T_{a}$ & $24.6(0.25)$ & $24.1(0.13)$ & $23.8(0.22)$ & $19.4(0.15)$ & $23.0(0.33)$ & $19.2(0.25)$ \\
\hline $\mathrm{RH}_{\mathrm{i}}$ & $53.3(0.57)$ & $62.8(0.28)$ & $75.3(0.43)$ & $73.3(0.51)$ & $74.8(0.75)$ & $74.9(0.78)$ \\
\hline $\mathrm{VPD}_{\mathrm{i}}$ & $1.6(0.20)$ & $1.3(0.19)$ & $0.8(0.60)$ & $0.6(0.01)$ & $0.8(0.32)$ & $0.6(0.02)$ \\
\hline$T_{c}-T_{a}$ & $-3.47(0.08)$ & $-1.42(0.07)$ & $-4.10(0.12)$ & $-2.10(0.15)$ & $-3.90(0.15)$ & $-2.09(0.16)$ \\
\hline \multirow[t]{2}{*}{$\mathrm{RG}_{\mathrm{i}}$} & \multicolumn{2}{|c|}{$333(3.70)$} & 253 & $.45)$ & 214 & .20) \\
\hline & & & & & & \\
\hline $\mathrm{T}_{\mathrm{o}}$ & 27.8 & $.11)$ & 28. & $.08)$ & 33.3 & $.08)$ \\
\hline $\mathrm{RH}_{\mathrm{o}}$ & 46.9 & $.34)$ & 50.8 & $.18)$ & 64.6 & $.52)$ \\
\hline $\mathrm{RG}_{\mathrm{o}}$ & 683 & $.51)$ & 667 & .26) & 728 & $47)$ \\
\hline & $\mathrm{W}-\mathrm{F}_{\mathrm{V}}$ & $\mathrm{F}-\mathrm{P}_{\mathrm{E}}$ & $\mathrm{W}-\mathrm{F}_{\mathrm{V}}$ & $\mathrm{F}-\mathrm{P}_{\mathrm{E}}$ & $\mathrm{W}-\mathrm{F}_{\mathrm{V}}$ & $\mathrm{F}-\mathrm{P}_{\mathrm{E}}$ \\
\hline$T_{a}$ & $29.3(0.12)$ & $28.1(0.12)$ & $28.7(0.08)$ & $27.3(0.07)$ & $33.3(0.09)$ & $31.4(0.09)$ \\
\hline $\mathrm{RH}_{\mathrm{i}}$ & $54.5(0.40)$ & $54.9(0.37)$ & $61.3(0.02)$ & $64.5(0.24)$ & $63.5(0.31)$ & $62.4(0.28)$ \\
\hline $\mathrm{VPD}_{\mathrm{i}}$ & $2.02(0.02)$ & $1.85(0.02)$ & $1.65(0.01)$ & $1.37(0.01)$ & $2.02(0.02)$ & $1.89(0.02)$ \\
\hline$T_{c}-T_{a}$ & $-2.38(0.05)$ & $-1.27(0.04)$ & $-2.59(0.02)$ & $-2.20(0.02)$ & $-3.04(0.04)$ & $-2.52(0.05)$ \\
\hline $\mathrm{RG}_{\mathrm{i}}$ & $363(5.22)$ & $460(6.62)$ & $352(3.98)$ & $446(5.05)$ & $385(2.46)$ & $489(4.93)$ \\
\hline
\end{tabular}

Exp.1, first experimental period (March to June); Exp.2, second experimental period (October to December); Exp.3, third experimental period (March to June); $\mathrm{T}_{\mathrm{o}}$, outside greenhouse air temperature $\left({ }^{\circ} \mathrm{C}\right) ; \mathrm{RH}_{\mathrm{o}}$, outside greenhouse air relative humidity $(\%) ; \mathrm{RG}_{0}$, outside greenhouse solar radiation $\left(\mathrm{W} \mathrm{m}^{-2}\right) ; \mathrm{iT}_{\mathrm{a}}$, internal greenhouse air temperature $\left({ }^{\circ} \mathrm{C}\right) ; \mathrm{RG}_{\mathrm{i}}$, internal greenhouse solar radiation $\left(\mathrm{W} \mathrm{m}^{-2}\right) ; \mathrm{RH}_{\mathrm{i}}$, inside greenhouse air relative humidity $(\%)$; $\mathrm{VPD}_{\mathrm{i}}$, internal greenhouse air vapor pressure deficit $(\mathrm{kPa}) ; T_{c}-T_{a}$, crop to air temperature difference $\left({ }^{\circ} \mathrm{C}\right)$; $\mathrm{F}_{\mathrm{V}}$, greenhouse span with a forced ventilation system; $\mathrm{F}-\mathrm{P}_{\mathrm{E}}$, greenhouse span with fan and pad evaporative cooling combined with natural and a forced air ventilation system; $\mathrm{W}-\mathrm{F}_{\mathrm{V}}$, greenhouse span with a forced air ventilation system combined with whitewash.

\subsection{Model Coefficients and Aerodynamic and Canopy Resistance Estimation}

A linear regression analysis between $T_{c}-T_{a}$ values derived from Equation (5) and measurements of VPD were computed in each climatic treatment $(n=5000)$ for the determination of intercept $(a)$ and slope (b) values (Figure 2). The relation between $T_{c}-T_{a}$ and VPD values was stronger in Exp.1 and Exp. 3 as indicated by a higher coefficient of determination $\left(\mathrm{r}^{2}\right)$; which was weaker in Exp.2 (Table 2). In the autumn-winter cropping period (March-June), the $\mathrm{r}^{2}$ values ranged from 0.65 to 0.82 (Exp.1 and Exp.3); during winter (Exp.2; October-December) the $r^{2}$ values were 0.29 and 0.39 . The lower $\mathrm{r}^{2}$ values were obtained in the greenhouse compartment with the fan and pad evaporative cooling system. Intercept recorded values were negative for both climatic treatments during Exp.3 (Table 2). 

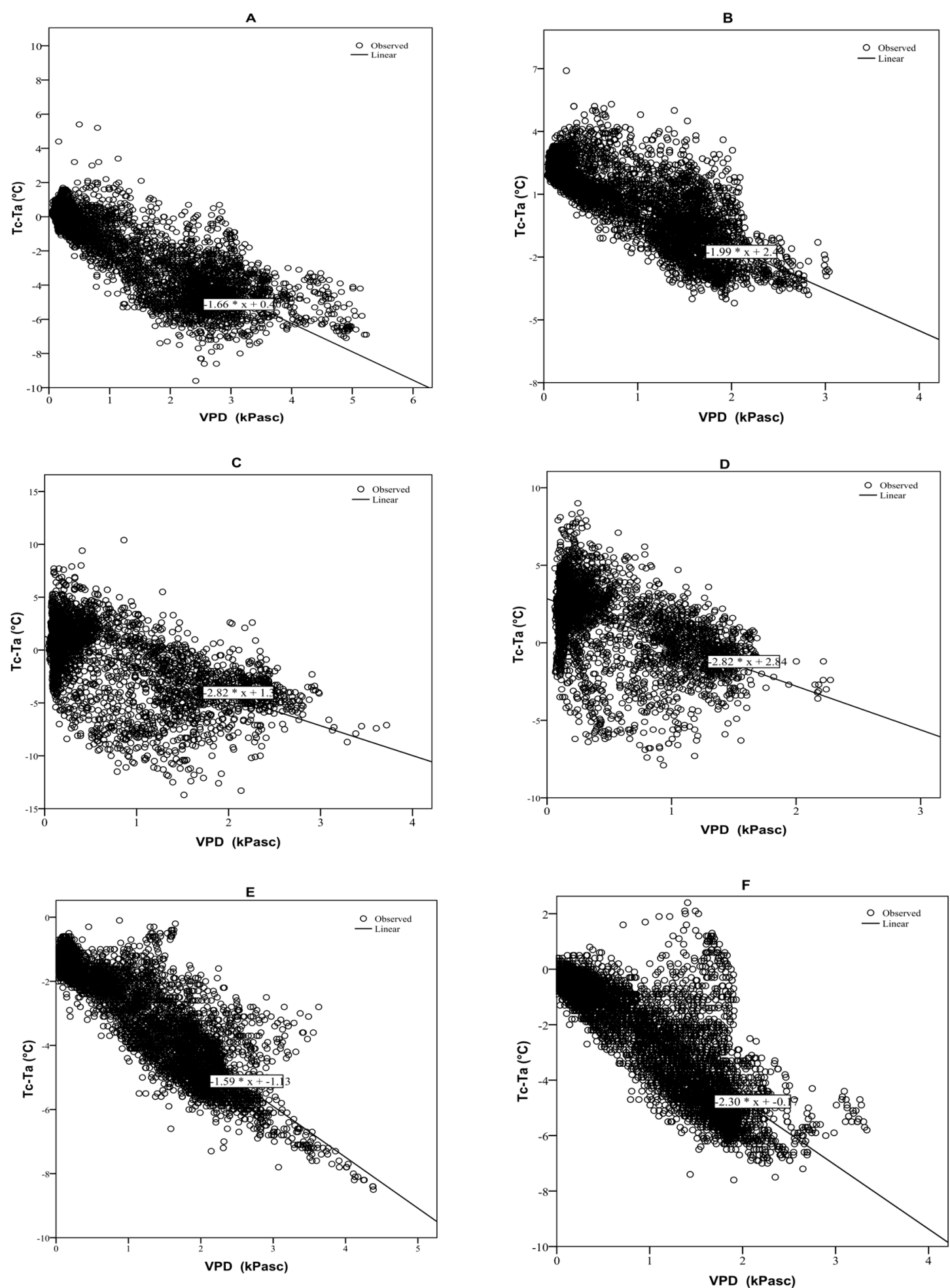

Figure 2. Relationship between canopy minus air temperature $\left(T_{c}-T_{a}\right)$ and water vapor pressure deficit (VPD); (A,B), first experimental period (March to June); (C,D), second experimental period (October to December); (E,F), third experimental period (March to June); $(\mathbf{A}, \mathbf{C})$, greenhouse span with a forced air ventilation system; (E), greenhouse span with a forced air ventilation system and whitewash; $(\mathbf{B}, \mathbf{D}, \mathbf{F})$, greenhouse span with a fan and pad evaporative cooling system combined with natural and a forced air ventilation system. 
Table 2. Intercepts $\left(\mathrm{a} ;{ }^{\circ} \mathrm{C}\right)$ and slopes $\left(\mathrm{b} ;{ }^{\circ} \mathrm{C} \mathrm{kPa}^{-1}\right)( \pm$ standard error) estimated based on a linear regression model of canopy-to-air temperature difference $\left(T_{c}-T_{a}\right)$ on VPD for daylight hours.

\begin{tabular}{ccccc}
\hline Climatic Treatment & Intercept (a) & Slope (b) & B & $\mathbf{r}^{\mathbf{2}}$ \\
\hline Exp.1, $\mathrm{F}_{\mathrm{V}}$ & $0.40(0.02)$ & $-1.66(0.01)$ & -0.87 & 0.75 \\
Exp.1, F-P $\mathrm{E}$ & $2.44(0.02)$ & $-1.99(0.01)$ & -0.80 & 0.65 \\
Exp.2, $\mathrm{F}_{\mathrm{V}}$ & $1.30(0.05)$ & $-2.81(0.05)$ & -0.62 & 0.39 \\
Exp.2, F-P $\mathrm{E}$ & $2.82(0.04)$ & $-2.84(0.06)$ & -0.54 & 0.29 \\
Exp.3; W-F & $-1.13(0.01)$ & $-1.59(0.01)$ & -0.90 & 0.82 \\
Exp.3; F- $\mathrm{P}_{\mathrm{E}}$ & $-0.17(0.01)$ & $-2.30(0.01)$ & -0.86 & 0.75
\end{tabular}

B, beta coefficient; $\mathrm{r}^{2}$, correlation coefficient; Exp.1, first experimental period (March to June); Exp.2, second experimental period (October to December); Exp.3, third experimental period (March to June); $\mathrm{F}_{\mathrm{V}}$, greenhouse span with a forced air ventilation system; F- $\mathrm{P}_{\mathrm{E}}$, greenhouse span with a fan and pad evaporative cooling system combined with natural and a forced air ventilation system; $\mathrm{W}-\mathrm{F}_{\mathrm{V}}$, greenhouse span with a forced air ventilation system and whitewash.

Using Equations (8) and (9), the aerodynamic and canopy resistance values were estimated in each climatic treatment on a ten-minute interval basis for daylight hours. Average resistances on a monthly basis and for each growing period are shown in Table 3. In addition, Table 3 shows the mean inside greenhouse solar radiation values for each experimental period as a direct link between radiation and canopy resistance values observed by many researchers [23,28,42].

Table 3. Mean calculated values ( \pm standard error) of aerodynamic $\bar{r}_{a p}\left(\mathrm{~s} \mathrm{~m}^{-1}\right)$ and canopy resistances $\bar{r}_{c p}\left(\mathrm{~s} \mathrm{~m}^{-1}\right)$.

\begin{tabular}{|c|c|c|c|c|c|}
\hline \multirow{2}{*}{ Climatic Treatment } & \multirow[b]{2}{*}{$\mathbf{R G}_{\mathrm{I}}$} & \multicolumn{4}{|c|}{$r_{a p}$} \\
\hline & & Mar. & Apr. & May & $\bar{r}_{a p}$ \\
\hline \multirow{3}{*}{$\begin{array}{l}\text { Exp.1, } \mathrm{F}_{\mathrm{V}} \\
\text { Exp.1, F-P }\end{array}$} & \multirow{2}{*}{$363(4.65)$} & $23(1.95)$ & $26(2.71)$ & $24(3.72)$ & $24(1.46)$ \\
\hline & & $61(3.59)$ & $65(4.69)$ & $69(7.22)$ & $64(2.66)$ \\
\hline & $\mathbf{R G}_{\mathrm{I}}$ & Oct. & Nov. & Dec. & $\bar{r}_{a p}$ \\
\hline \multirow{3}{*}{$\begin{array}{c}\text { Exp.2, } \mathrm{F}_{\mathrm{V}} \\
\text { Exp.2, F-P } \mathrm{P}_{\mathrm{E}}\end{array}$} & \multirow{2}{*}{$249(3.92)$} & $64(5.81)$ & $63(6.33)$ & $50(6.43)$ & $61(3.69)$ \\
\hline & & $86(6.54)$ & $83(7.41)$ & 78 (7.13) & $83(4.20)$ \\
\hline & $\mathbf{R G}_{\mathrm{I}}$ & Mar. & Apr. & May & $\bar{r}_{a p}$ \\
\hline Exp.3, W-F & 327 (3.23) & 35 (5.19) & $45(2.70)$ & $42(4.15)$ & $43(2.08)$ \\
\hline \multirow[t]{3}{*}{ Exp.3, F-P ${ }_{\mathrm{E}}$} & $368(4.11)$ & $25(3.93) \mathrm{a}$ & $48(2.37) \mathrm{b}$ & $54(3.97) \mathrm{c}$ & $47(1.86)$ \\
\hline & & \multicolumn{4}{|c|}{$\bar{r}_{c p}$} \\
\hline & $\mathrm{RG}_{\mathrm{I}}$ & Mar. & Apr. & May & $\bar{r}_{c p}$ \\
\hline \multirow{3}{*}{$\begin{array}{c}\text { Exp.1, F } \\
\text { Exp.1, F-P }\end{array}$} & $363(4.65)$ & $60(3.73)$ & $60(4.62)$ & $62(6.81)$ & $60(2.67)$ \\
\hline & $000(+.00)$ & 147 (6.25) & $152(8.31)$ & 154 (11.30) & $150(4.57)$ \\
\hline & $\mathbf{R G}_{\mathrm{I}}$ & Oct. & Nov. & Dec. & $\bar{r}_{c p}$ \\
\hline \multirow{3}{*}{$\begin{array}{c}\text { Exp.2, } \mathrm{F}_{\mathrm{V}} \\
\text { Exp.2, F-P }\end{array}$} & $249(3.92)$ & $82(7.38)$ & 75 (7.01) & $85(8.81)$ & $80(4.52)$ \\
\hline & $249(3.92)$ & $120(7.86)$ ac & $125(9.00) \mathrm{bc}$ & $172(15.62) \mathrm{cab}$ & $132(5.65)$ \\
\hline & $\mathrm{RG}_{\mathrm{I}}$ & Mar. & Apr. & May & $\bar{r}_{c p}$ \\
\hline Exp.3, W-FV & 327 (3.23) & 127 (9.37) ab & 152 (4.91) bac & $133(7.28) \mathrm{cb}$ & $144(3.75)$ \\
\hline Exp3, F-P $\mathrm{E}$ & $368(4.11)$ & 92 (14.53) abc & 167 (8.24) ba & 179 (13.17) са & $161(6.39)$ \\
\hline
\end{tabular}

Exp.1, first experimental period (March to June); Exp.2, second experimental period (October to December); Exp.3, third experimental period (March to June); $\mathrm{F}_{\mathrm{V}}$, greenhouse span with a forced air ventilation system; F- $\mathrm{P}_{\mathrm{E}}$, greenhouse span with a fan and pad evaporative cooling system combined with natural and a forced air ventilation system. $\mathrm{W}-\mathrm{F}_{\mathrm{V}}$, greenhouse span with a forced ventilation system and whitewash; $R G_{\mathrm{I}}$, inside greenhouse solar radiation $\left(\mathrm{W} \mathrm{m}^{-2}\right)$. Means within columns followed by the same letter are not significantly different according to Duncan's multiple range test at $p \leq 0.05$. 
The values of $r_{a p}$ and $r_{c p}$ calculated in the forced air ventilation climatic treatment were lower than those found in the greenhouse span with the fan and pad evaporative cooling system. The mean monthly $r_{a p}$ values varied from 23 to $86 \mathrm{~s} \mathrm{~m}^{-1}$, and $r_{c p}$ varied from 60 to $179 \mathrm{~s} \mathrm{~m}^{-1}$. The highest $r_{a p}$ values were estimated in Exp.2, and the highest $r_{c p}$ values in Exp.3. Under lower solar radiation values in Exp.2, $r_{c p}$ values declined and $r_{a p}$ values increased. Considering mean monthly differences in resistances, statistically significant differences were observed in some cases for $r_{c p}$ values rather than for $r_{a p}$ (Table 3).

\subsection{Model Validation}

Model validation showed a good fit between simulated and measured transpiration values. In Exp.1, when the P-M model were parameterized with the $\bar{r}_{a p}$ and $\bar{r}_{c p}$ values during the same growing period, the coefficient of determination $\left(\mathrm{r}^{2}\right)$ between measured and estimated transpiration was 0.80 in $\mathrm{F}_{\mathrm{V}}$ and $\mathrm{r}^{2}=0.78$ in F-P $\mathrm{P}_{\mathrm{E}}$. High regression coefficients were also obtained when the $\bar{r}_{a p}$ and $\bar{r}_{c p}$ in Exp.2 and Exp.3 were used for calculating transpiration rate in Exp.1, within the same climatic treatments (Table 4 ).

Table 4. Linear regression coefficient of determination $\left(\mathrm{r}^{2}\right)$, between transpiration estimated by the Penman-Monteith model based on calculated aerodynamic and canopy resistances and values measured with lysimeters for a 10-day period during daylight hours.

\begin{tabular}{cccccccc}
\hline & \multicolumn{7}{c}{ Experimental Period 1 } \\
\hline Climatic Treatment & $\bar{r}_{\boldsymbol{a} \boldsymbol{p}}$ & $\overline{\boldsymbol{r}}_{\boldsymbol{c} \boldsymbol{p}}$ & $\mathbf{T}_{\mathbf{r m}}$ & $\mathbf{T}_{\mathbf{r e}}$ & Slope (b) & $\mathbf{r}^{\mathbf{2}}$ & $\mathbf{n}$ \\
\hline Exp.1, $\mathrm{F}_{\mathrm{V}}$ & 24 & 60 & 351 & 437 & 0.74 & 0.80 & 441 \\
Exp.2, $\mathrm{F}_{\mathrm{V}}$ & 61 & 80 & 354 & 381 & 0.83 & 0.78 & 441 \\
Exp.3, W-F & 43 & 144 & 349 & 315 & 0.99 & 0.77 & 446 \\
Exp.1, F-P & 64 & 150 & 223 & 260 & 0.78 & 0.77 & 489 \\
Exp.2, F-P & 83 & 132 & 222 & 281 & 0.72 & 0.76 & 410 \\
Exp.3, F-P & 47 & 161 & 222 & 238 & 0.86 & 0.76 & 411 \\
\hline
\end{tabular}

Parameterized $\bar{r}_{a p}$ and $\bar{r}_{c p}$ values used for the P-M model validation in Exp.1. Values of $\bar{r}_{a p}$ and $\bar{r}_{c p}$ (Exp.2 and Exp.3) used for the P-M model validation in Exp.1 within $\mathrm{F}_{\mathrm{V}}$ and F-P $\mathrm{P}_{\mathrm{E}}$. Exp.1, first experimental period (March to June); Exp.2, second experimental period (October to December); Exp.3, third experimental period (March to June); $\mathrm{F}_{\mathrm{V}}$, greenhouse span with a forced air ventilation system; $\mathrm{F}-\mathrm{P}_{\mathrm{E}}$, greenhouse span with a fan and pad evaporative cooling system combined with natural and a forced air ventilation system. $\mathrm{W}-\mathrm{F}_{\mathrm{V}}$, greenhouse span with a force ventilation system and whitewash; $\mathrm{T}_{\mathrm{rm}}$, measured transpiration rate $\left(\mathrm{W} \mathrm{m}^{-2}\right) ; \mathrm{T}_{\mathrm{re}}$, estimated transpiration rate $\left(\mathrm{W} \mathrm{m}{ }^{-2}\right) ; \mathrm{n}$, number of observations.

\section{Discussion}

In this study, the effect of prevailing greenhouse microclimate on aerodynamic and canopy resistance values of a hydroponically grown cucumber crop in a plastic greenhouse was determined. Common greenhouse climate control equipment was used, as per usual, local greenhouse grower practices, for alleviating the excessive heat load that is usually observed year-round in Mediterranean climate conditions.

Canopy-to-air temperature difference is a well-known indicator of crop stress dependent on crop water status and the micrometeorological environment $[34,43]$. This study shows that fan and pad evaporative cooling was the most efficient system to decrease the VPD and the greenhouse air and leaf temperatures. The canopy-to-air temperature difference, within the same growing period, was higher in the forced air ventilation treatment as the VPD increased. Gázquez et al. [44] reported similar results when comparing natural ventilation with a fog cooling system in a hydroponically-grown pepper crop. They observed higher pepper transpiration values as the VPD and greenhouse air temperature increased. In addition, a positive correlation between VPD and the greenhouse air exchange rate was reported by Seginer $[45,46]$. However, despite the lower VPD values in Exp.2 (October-December) compared to Exp.1 and Exp.3 (March-May), higher $T_{c}-T_{a}$ differences were observed (Table 1). This was due to the lower greenhouse air temperatures (Table 1). In any case, a stronger linear regression coefficient between $T_{c}-T_{a}$ and VPD was calculated in Exp.1 and Exp.3 
compared to Exp.2 (Table 2). Notably, only a linear relationship between $T_{\mathcal{c}}-T_{a}$ and VPD was reported by other researchers, a higher regression coefficient was obtained under clear-sky conditions.

Aerodynamic $\left(r_{a p}\right)$ and canopy resistance $\left(r_{c p}\right)$ values were lower with forced air ventilation than with a fan and pad evaporative cooling system (Table 3 ). It is well known that $r_{a}$ is related to the air speed (aerodynamic regime). Consequently, it seems that the intensive work of fans in the forced air ventilation treatment induced an excessive air exchange rate, which resulted in lower $r_{a p}$ values. In Exp.1, the difference in $r_{a p}$ between climatic treatments was $63 \mathrm{~s} \mathrm{~m}^{-1}$, declined to $22 \mathrm{~s} \mathrm{~m}^{-1}$ in Exp.2 (the greenhouse was kept closed for longer period during the day) and further declined to $4 \mathrm{~s} \mathrm{~m}^{-1}$ in Exp.3. In the latter case, smaller differences between climatic treatments were found, as whitewash application reduce the incoming solar radiation values in the forced air ventilated compartment. The internal-external air exchange rate was also the reason for smaller air humidity differences between climatic treatments (even though water evaporated directly into the one compartment). In November and December (Exp.2), the differences between climatic treatments of internal relative humidity were larger and the mean values higher than those of the ambient humidity.

Although in the majority of the energy balance models, $r_{a p}$ values are assumed to be constant, however, that hypothesis may not be valid in the case of highly ventilated Mediterranean greenhouses [45]. Nevertheless, significant monthly differences in $r_{a p}$ values were observed only in Exp.3. In our case, the mean $r_{a p}$ values during the growing period ranged from 24 to $83 \mathrm{~s} \mathrm{~m}^{-1}$. However, Fernández et al. [29] working with a soil-based crop grown in a passive manually- ventilated, plastic, whitewashed greenhouse in a Mediterranean climate used a much higher constant $r_{a}$ value. Bouhoun Ali et al. [3], in a passive roof ventilated glasshouse, used a constant $r_{a}$ value of $271 \mathrm{~s} \mathrm{~m}^{-1}$. For a solar greenhouse in China, Gong et al. [15], used a constant $r_{a}$ value of $308 \mathrm{~s} \mathrm{~m}^{-1}$. On the other hand, the estimated mean $r_{a p}$ values for several vegetables reported by O'Toole and Real (1986) ranged between 4 and $14 \mathrm{~s} \mathrm{~m}^{-1}$. Additionally, Yan et al. [26] suggested that the latent heat fluxes were not affected by changes in daily aerodynamic resistances; therefore, they used a fix daily value of $r_{a}=35 \mathrm{~s} \mathrm{~m}^{-1}$ for soilless cucumber crop. In any case, Boulard and Wang [47] expressed the $r_{a}$ as a function of specific crop characteristic (length of a leaf) and mean greenhouse air speed.

Although several researchers studied the effect of VPD on crop stomatal conductance $\left(r_{c}\right.$ is the inverse of stomatal conductance), conflicting results often occurred. Bakker [48] observed a $65 \%$ reduction in stomatal conductance when the VPD increased by $1 \mathrm{kPa}$. In contrast, Montero et al. [42] suggested that that there is no clear evidence that stomatal conductance is directly affected by VPD as no significant reduction in crop stomatal conductance was observed when the VPD increased from $1.4 \mathrm{kPa}$ to $3.4 \mathrm{kPa}$. Measurements in Mediterranean greenhouses showed that the use of a fog cooling system increased crop stomatal conductance and indicated that maximum values of crop stomatal conductance were observed when solar radiation exceeded $300 \mathrm{~W} \mathrm{~m}^{-2}$ [28,49]. In our case, we lowered the mean canopy resistance value estimation by $60 \%$, irrespective of the growing period in the forced air ventilation treatment compared to the fan and pad evaporative cooling system. In part, that was due to the higher VPD under the forced air ventilation treatment. The mean estimated values were between 60 and $161 \mathrm{~s} \mathrm{~m}^{-1}$ within different climatic treatments. Villarreal-Guerrero et al. [50], working with hydroponically grown crops in a greenhouse with an active cooling system, estimated average $r_{c}$ values of $59 \mathrm{~s} \mathrm{~m}^{-1}$ for pepper and $70 \mathrm{~s} \mathrm{~m}^{-1}$ for tomato. Yan et al. [26] supported that the days after transplanting constituted the factor that significantly affected the $r_{c}$ values rather than other climatic conditions variables. According to the same author, the cucumber $r_{c}$ declined to less than $100 \mathrm{~s} \mathrm{~m}^{-1}$ as the plants grew.

Our results suggest that the intensive work of fans leads to excessive air exchange in the forced air ventilation climate and induces higher VPD values, which could be the reason for the higher transpiration rate (see Nikolaou et al. [6]) and lower $r_{c}$ values. This was due to the fact that VPD values were in the range of $2 \mathrm{kPa}$, indicating non-stressed crop conditions. Shibuya et al. [51] concluded that an increase in the VPD could increase the cucumber transpiration rate. However, in the case of much higher mean VPD values, stomatal functioning is expected to be negatively affected, and higher $r_{c}$ values should be obtained. 
The differences in the greenhouse construction type and climate monitoring equipment used may had a direct effect on aerodynamic resistance. In addition, leaf age and leaf area index, as well as different cultivation techniques, may also had a direct effect on canopy resistance. Furthermore, canopy temperature was not based on a dedicated sensing network covering the entire area of the greenhouse and therefore may not represent the real temperature of the canopy. Overall, a high linear coefficient of determination was observed between estimates using the Penman-Monteith model based on parameterized aerodynamic $\left(\bar{r}_{a p}\right)$ and canopy resistance $\left(\bar{r}_{c p}\right)$ and values measured with lysimeters.

\section{Conclusions}

Experiments were conducted in a Mediterranean climate for the parameterization of aerodynamic and canopy resistance values of a soilless cucumber crop based on instantaneous leaf temperature measurements. Crop and aerodynamic resistance values were affected by the cropping period and the greenhouse climate control equipment. Estimated mean aerodynamic and canopy resistance values were successfully fitted for different growing periods using the Penman-Monteith equation. Results may be helpful for greenhouse climate control monitoring systems and estimation of transpiration models under similar climatic conditions.

Author Contributions: Formal analysis, G.N.; investigation, G.N.; methodology, G.N. and D.N.; supervision, D.N. and N.K.; writing, G.N., N.K., E.K. and D.N. All authors have read and agreed to the published version of the manuscript.

Funding: This research received no external funding

Conflicts of Interest: The authors declare no conflict of interest.

\section{Abbreviations}

Exp.1 First experimental period (March to June)

Exp.2 Second experimental period (October to December)

Exp.3 Third experimental period (March to June)

F- $P_{\mathrm{E}} \quad$ Greenhouse span with a fan and pad evaporative cooling combined with natural and a forced air

ventilation system

$\mathrm{F}_{\mathrm{V}} \quad$ Greenhouse span with a forced air ventilation system

$r_{a} \quad$ Resistance from the vegetation upward which involves friction from air flowing over vegetative surfaces

$\mathrm{RG}_{\mathrm{i}} \quad$ Internal greenhouse solar radiation

$R G_{0} \quad$ Outside greenhouse solar radiation

$\mathrm{RH}_{\mathrm{i}} \quad$ Internal greenhouse air relative humidity

$\mathrm{RH}_{\mathrm{O}} \quad$ Outside greenhouse air relative humidity

$r_{s} \quad$ Resistance of vapor flow through stomatal openings, the total leaf area and the soil surface

$T_{a} \quad$ Inside greenhouse air temperature

$T_{c}-T_{a}$ Canopy-to-air temperature differences

$\mathrm{T}_{\mathrm{O}} \quad$ Outside greenhouse air temperature

VPD Air vapor pressure deficit

W-F $F_{V}$ Greenhouse span with a forced ventilation system combined with whitewash

\section{References}

1. Katsoulas, N.; Kittas, C. Greenhouse Crop Transpiration Modelling, Evapotranspiration from Measurements to Agricultural and Environmental Applications; Giacomo, G., Ed.; InTech: London, UK, 2011; ISBN 978-953-307-512-9. Available online: http://Www.Intechopen.Com/Books/Evapotranspiration-fromMeasurements-to-Agricultural-and-Environmental-Applications/Greenhouse-Crop-Transpiration-Modelling (accessed on 15 September 2020).

2. Boulard, T.; Roy, J.-G.; Pouillard, J.-B.; Fatnassi, H.; Grisey, A. Modelling of Micrometeorology, Canopy Transpiration and Photosynthesis in a Closed Greenhouse Using Computational Fluid Dynamics. Biosyst. Eng. 2017, 158, 110-133. [CrossRef] 
3. Bouhoun Ali, H.; Bournet, P.-E.; Cannavo, P.; Chantoiseau, E. Development of a CFD Crop Submodel for Simulating Microclimate and Transpiration of Ornamental Plants Grown in a Greenhouse under Water Restriction. Comput. Electron. Agric. 2018, 149, 26-40. [CrossRef]

4. Kimura, K.; Yasutake, D.; Yamanami, A.; Kitano, M. Spatial examination of leaf-boundary-layer conductance using artificial leaves for assessment of light airflow within a plant canopy under different controlled greenhouse conditions. Agric. For. Meteorol. 2020, 280, 107773. [CrossRef]

5. Kittas, C.; Katsoulas, N.; Baille, A. Influence of Crop Leaf Area Index on Greenhouse Cooling Requirements. In Proceedings of the International Conference on the Integration of the Renewable Energy Systems into the Buildings Structures, Patra, Greece, 7-10 July 2005.

6. Nikolaou, G.; Neocleous, D.; Katsoulas, N.; Kittas, C. Effects of Cooling Systems on Greenhouse Microclimate and Cucumber Growth under Mediterranean Climatic Conditions. Agronomy 2019, 9, 300. [CrossRef]

7. Graamans, L.; van Den Dobbelsteen, A.; Meinen, E.; Stanghellini, C. Plant Factories; Crop Transpiration and Energy Balance. Agric. Syst. 2017, 153, 138-147. [CrossRef]

8. Allen, R.; Pereira, L.; Raes, D.; Smith, M. Crop Evapotranspiration Guidelines for Computing Crop Water Requirements. In FAO Irrigation and Drainage Paper, 56; FAO: Rome, Italy, 1998; pp. 1-289.

9. Alves, I.; Perrier, A.; Pereira, L.S. Aerodynamic and Surface Resistances of Complete Cover Crops: How Good Is the "Big Leaf"? Trans. Am. Soc. Agric. Eng. 1998, 41, 345-351. [CrossRef]

10. Katsoulas, N.; Stanghellini, C. Modelling Crop Transpiration in Greenhouses: Different Models for Different Applications. Agronomy 2019, 7, 392. [CrossRef]

11. Monteith, J.L. Evaporation from Land Surfaces: Progress in Analysis and Prediction since 1948. In Advances in Evapotranspiration. In Proceedings of the National Conference on Advance in Evapotranspiration, Chicago, IL, USA, 16-17 December 1985.

12. Allen, R.G.; Pruitt, W.O.; Wright, J.L.; Howell, T.A.; Ventura, F.; Snyder, R.; Itenfisu, D.; Steduto, P.; Berengena, J.; Yrisarry, J.B.; et al. A Recommendation on Standardized Surface Resistance for Hourly Calculation of Reference ETo by the FAO56 Penman-Monteith Method. Agric. Water Manag. 2006, 81, 1-22. [CrossRef]

13. Qiu, R.; Kang, S.; Du, T.; Tong, L.; Hao, X.; Chen, R.; Chen, J.; Li, F. Effect of Convection on the Penman-Monteith Model Estimates of Transpiration of Hot Pepper Grown in Solar Greenhouse. Sci. Hortic. 2013, 160, 163-171. [CrossRef]

14. Wallach, R. Physical Characterisrtics of Soilless Media. In Soilless Culture: Theory and Practice, 1st ed.; Raviv, M., Lieth, J.H., Eds.; Elsevier: London, UK, 2008; pp. 117-155.

15. Gong, X.; Liu, H.; Sun, J.; Gao, Y.; Zhang, X.; Jha, S.K.; Zhang, H.; Ma, X.; Wang, W. A Proposed Surface Resistance Model for the Penman-Monteith Formula to Estimate Evapotranspiration in a Solar Greenhouse. J. Arid Land 2017, 9, 530-546. [CrossRef]

16. Tolk, J.A. Corn Aerodynamic and Canopy Surface Resistances and Their Role in Sprinkler Irrigation Efficiency. A Dissertation in Agronomy. Ph.D. Thesis, Graduate Faculty of Texas Tech University, Texas, TX, USA, 1992.

17. Thom, A.S. Momentum, Mass and Heat Exchange of Plant Communities. In Vegetation and the Atmosphere; Monteith, J.L., Ed.; Academic Press: London, UK, 1975; pp. 57-109.

18. Fernandes, C.; Corá, J.; Araújo, J. Reference Evapotranspiration Estimation inside Greenhouses. Sci. Agric. 2003, 60, 591-594. [CrossRef]

19. Nikolaou, G.; Neocleous, D.; Katsoulas, N.; Kittas, C. Modelling Transpiration of Soilless Greenhouse Cucumber and Its Relationship with Leaf Temperature in a Mediterranean Climate. Emir. J. Food Agric. 2017, 29, 911-920. [CrossRef]

20. Alarcón, J.J.; Ortuño, M.F.; Nicolás, E.; Navarro, A.; Torrecillas, A. Improving Water-Use Efficiency of Young Lemon Trees by Shading with Aluminised-Plastic Nets. Agric. Water Manag. 2006, 82, 387-398. [CrossRef]

21. Hernandez, M.J.; Montes, F.; Ruiz, F.; Lopez, G.; Pita, P. The Effect of Vapour Pressure Deficit on Stomatal Conductance, Sap PH and Leaf-Specific Hydraulic Conductance in Eucalyptus Globulus Clones Grown under Two Watering Regimes. Ann. Bot. 2016, 117, 1063-1071. [CrossRef]

22. Lin, B.-S.; Lei, H.; Hu, M.-C.; Visessri, S.; Hsieh, C.-I. Canopy Resistance and Estimation of Evapotranspiration above a Humid Cypress Forest. Adv. Meteorol. 2020. [CrossRef]

23. Rouphael, Y.; Colla, G. Modelling the Transpiration of a Greenhouse Zucchini Crop Grown under a Mediterranean Climate Using the Penman-Monteith Equation and Its Simplified Version. Crop Pasture Sci. 2004, 55, 931-993. [CrossRef] 
24. Kittas, C.; Katsoulas, N.; Baille, A. Transpiration and Canopy Resistance of Greenhouse Soilless Roses: Measurements and Modeling. Acta Hortic. 1999, 507, 61-68. [CrossRef]

25. Zolnier, S.; Lyra, G.; Gates, R.S. Evapotranspiration Estimates for Greenhouse Lettuce Using an Intermittent Nutrient Film Technique. Trans. Asabe 2004, 47, 271-282. [CrossRef]

26. Yan, H.; Huang, S.; Zhang, C.; Gerrits, M.C.; Wang, G.; Zhang, J.; Zhao, B.; Acquah, S.J.; Wu, H.; Fu, H. Parameterization and Application of Stanghellini Model for Estimating Greenhouse Cucumber Transpiration. Water 2020, 12, 517. [CrossRef]

27. Wang, S.; Boulard, T.; Haxaire, R. Air Speed Profiles in a Naturally Ventilated Greenhouse with a Tomato Crop. Agric. For. Meteorol. 1999, 96, 181-188.

28. Baille, M.; Baille, A.; Laury, J.C. A Simplified Model for Predicting Evapotranspiration Rate of Nine Ornamental Species vs Climate Factors and Leaf Area. Sci. Hortic. 1994, 59, 217-232. [CrossRef]

29. Fernández, M.D.; Bonachela, S.; Orgaz, F. Measurement and Estimation of Plastic Greenhouse Reference Evapotranspiration in a Mediterranean Climate. Irrig. Sci. 2010, 28, 497-509. [CrossRef]

30. Nikolaou, G.; Neocleous, D.; Katsoulas, N.; Kittas, C. Dynamic Assessment of Whitewash Shading and Evaporative Cooling on the Greenhouse Microclimate and Cucumber Growth in a Mediterranean Climate. Ital. J. Agrometeorol. 2018, 2, 15-26.

31. Katsoulas, N.; Kittas, C.; Dimokas, G.; Lykas, C. Effect of Irrigation Frequency on Rose Flower Production and Quality. Biosyst. Eng. 2006, 93, 237-244. [CrossRef]

32. Beeson, R.C., Jr. Weighing Lysimeter Systems for Quantifying Water Use and Studies of Controlled Water Stress for Crops Grown in Low Bulk Density Substrates. Agric. Water Manag. 2011, 98, 967-976. [CrossRef]

33. Savvas, D.; Gianquinto, G.P.; Tüzel, Y.; Gruda, N. Soilless Culture. In Good Agricultural Practices for Greenhouse Vegetable Crops. Principles for Mediterranean Climate Area; Plant Production and Protection Paper, 217; Baudoin, W., Nomo-Wondim, R., Lutaladio, N., Hobber, A., Castilla, N., Leonardi, C., De Pascale, S., Qaryouti, M., Duffy, R., Eds.; Food and Agricultural Organization of the United Nations (FAO): Rome, Italy, 2013; pp. 303-354.

34. Jackson, R.D.; Idso, S.B.; Reginato, R.J.; Pinter, P.J. Canopy Temperature as a Crop Water Stress Indicator. Water Resour. Res. 1981, 17, 1133-1138.

35. Vermeulen, K.; Aerts, J.M.; Dekock, J.; Bleyaert, P.; Berckmans, D.; Steppe, K. Automated Leaf Temperature Monitoring of Glasshouse Tomato Plants by Using a Leaf Energy Balance Model. Comput. Electron. Agric. 2012, 87, 19-31. [CrossRef]

36. Takakura, T.; Kubota, C.; Sase, S.; Hayashi, M.; Ishii, M.; Takayama, K.; Nishina, H.; Kurata, K.; Giacomelli, G.A. Measurement of Evapotranspiration Rate in a Single-Span Greenhouse Using the Energy-Balance Equation. Biosyst. Eng. 2009, 102, 298-304. [CrossRef]

37. Jackson, R.D.; Kustas, W.P.; Choudhury, B.J. A Reexamination of the Crop Water Stress Index. Irrig. Sci. 1998, 9, 309-317. [CrossRef]

38. Gontia, N.K.; Tiwari, K.N. Development of Crop Water Stress Index of Wheat Crop for Scheduling Irrigation Using Infrared Thermometry. Agric. Water Manag. 2008, 95, 1144-1152. [CrossRef]

39. van Bavel, C.H.M.; Ehrler, W.L. Water Loss from a Sorghum Field and Stomatal Control. Agron. J. 1968, 60, 84-86. [CrossRef]

40. Ehrler, W.L. Cotton Leaf Temperatures as Related to Soil Water Depletion and Meteorological Factors. Agron. J. 1973, 65, 404-409. [CrossRef]

41. O'Toole, J.C.; Real, J.G. Estimation of Aerodynamic and Crop Resistances from Canopy Temperature. Agron. J. 1986, 78, 305-310. [CrossRef]

42. Montero, J.I.; Antón, A.; Muûoz, P. Transpiration from Geranium Grown under High Temperatures and Low Humidities in Greenhouses. Agric. For. Meteorol. 2001, 107, 323-332. [CrossRef]

43. O'Toole, J.C.; Hatfield, J.L. Effect of Wind on the Crop Water Stress Index Derived by Infrared Thermometry. Agron. J. 1983, 75, 811-817. [CrossRef]

44. Gázquez, J.C.; López, J.C.; Pérez-Parra, J.J.; Baeza, E.J.; Saéz, M.; Parra, A. Greenhouse Cooling Strategies for Mediterranean Climate Areas. Acta Hortic. 2008, 801, 425-432. [CrossRef]

45. Ido Seginer, I. Transpirational Cooling of a Greenhouse Crop with Partial Ground Cover. Agric. Forest Meteorol. 1994, 71, 265-281. [CrossRef] 
46. Acquah, S.; Yan, H.; Zhang, C.; Wang, G.; Zhao, B.; Wu, H.; Zhang, H. Application and Evaluation of Stanghellini Model in the Determination of Crop Evapotranspiration in a Naturally Ventilated Greenhouse. Int. J. Agric. Biol. Eng. 2018, 11, 95-103.

47. Boulard, T.; Wang, S. Greenhouse Crop Transpiration Simulation from External Climate Conditions. Agric. For. Meteorol. 2000, 100, 25-34. [CrossRef]

48. Bakker, J.C. Leaf conductance of four glasshouse vegetable crop as affected by air humidity. Agric. For. Meteorol. 1991, 55, 23-36. [CrossRef]

49. Katsoulas, N.; Baille, A.; Kittas, C. Effect of Misting on Transpiration and Conductances of a Greenhouse Rose Canopy. Agric. For. Meteorol. 2001, 106, 233-247. [CrossRef]

50. Villarreal-Guerrero, F.; Kacira, M.; Fitz-Rodríguez, E. Simulated Performance of a Greenhouse Cooling Control Strategy with Natural Ventilation and Fog Cooling. Biosyst. Eng. 2012, 111, 217-228. [CrossRef]

51. Shibuya, T.; Sugimoto, A.; Kitaya, Y.; Kiyota, M.; Nagasaka, Y.; Kawaguchi, S. Measurement of Leaf Vapor Conductance of Cucumber Transplants in the Greenhouse with Minimal Invasion. HortScience 2010, 45, 460-462. Available online: Https://Journals.Ashs.Org/Hortsci/View/Journals/Hortsci/45/3/Article-P460.Xml (accessed on 17 October 2020). [CrossRef]

Publisher's Note: MDPI stays neutral with regard to jurisdictional claims in published maps and institutional affiliations.

(C) 2020 by the authors. Licensee MDPI, Basel, Switzerland. This article is an open access article distributed under the terms and conditions of the Creative Commons Attribution (CC BY) license (http://creativecommons.org/licenses/by/4.0/). 